\title{
Inovasi Teknologi Pakan Komplit (Complete Feed) Sapi Potong Berbasis Limbah Agroindustri di Kabupaten Subang
}

\author{
Nurul Mukminah, 1*, Irna Dwi Destiana², Wiwik Endah Rahayu3 ${ }^{3}$, dan Enceng Sobari4 \\ Program Studi Agroindustri, Politeknik Negeri Subang \\ Jl.Brigjen Katamso No. 37, Subang, Jawa Barat, Indonesia \\ ${ }^{1 *}$ nurulmukminah24@gmail.com \\ Program Studi Agroindustri, Politeknik Negeri Subang \\ Jl.Brigjen Katamso No. 37, Subang, Jawa Barat, Indonesia \\ irnadwidestiana@gmail.com \\ Program Studi Agroindustri, Politeknik Negeri Subang \\ Jl.Brigjen Katamso No. 37, Subang, Jawa Barat, Indonesia \\ 3indayu.sk@gmail.com \\ Program Studi Agroindustri, Politeknik Negeri Subang \\ Jl.Brigjen Katamso No. 37, Subang, Jawa Barat, Indonesia \\ 4ncesobari@gmail.com
}

Artikel diterima: 11-10-2019, direvisi: 12-11-2019, diterbitkan: 05-12-2019

\begin{abstract}
Abstrak
Rendahnya produktivitas sapi di KTT Budi Asih disebabkan mahalnya harga konsentrat dan minimnya nutrisi pakan yang diberikan. Salah satu satu alternatif bahan pakan yang dapat digunakan untuk mengatasi kendala tersebut yaitu penggunaan limbah agroindustri yang melimpah dan belum termnafaat di Kabupaten Subang. Oleh sebab itu perlu upaya untuk pembuatan pakan berbasis limbah agroindustri yang murah, bernutrisi, dan kontinyu. Tujuan dari pengabdian ini adalah memanfaatkan limbah agroindustri berupa ampas kecap sebagai bahan penyusun complete feed solusi pakan mahal dan memberikan penyuluhan serta pelatihan pembuatan complete feed kepada masyarakat. Luaran yang hendak dicapai adalah meningkatkan pengetahuan dan ketrampilan peternak untuk pengembangan dan pembuatan complete feed dari limbah agroindustri. Metode dalam pengabdian ini adalah FGD dengan peternak, penyuluhan pelatihan pembuatan pakan, penyerahan pakan komplit, monitoring dan evaluasi. Berdasarkan hasil kegiatan pengabdian kepada masyarakat yang telah dilaksanakan, dapat disimpulkan bahwa pelatihan pembuatan complete feed dengan menggunakan limbah agroindustri dapat menekan biaya produksi serta meningkatkan produktivitas ternak berupa peningkatan $\mathrm{PBBH}$.

Kata Kunci: KTT Budi Asih, Limbah agroindustri, Pakan komplit, sapi potong
\end{abstract}

\section{Pendahuluan}

Kelompok Tani Ternak (KTT) Budi Asih merupakan salah satu KTT yang berada di

Kecamatan Cipunagara. KTT in beranggotakan 18 orang peternak dengan jumlah ternak sapi potong sebanyak 47 ekor. Kecamatan Cipunagara merupakan salah satu kecamatan di Kabupaten 
Subang yang menjadi wilayah Sentra Peternakan Rakyat. Menurut Puslitbangnak (2016), Kementerian Pertanian telah menetapkan Kabupaten Subang sebagai salah satu lokasi pilot project Kawasan Peternakan Sapi Potong di Jawa Barat.

Produktivitas ternak sapi yang ada di lokasi mitra memiliki produktivitas yang cukup rendah. Hal ini terlihat dari lamanya proses pemeliharaan ternak yang hanya mampu panen satu tahun sekali. Pakan menjadi salah satu faktor penentu keberhasilan produktivitas ternak. Penyediaan pakan yang sesuai untuk ternak akan mempercepat proses pembesaran dan pemeliharan ternak.

Kondisi yang terjadi di lapangan, ternak yang dipelihara hanya diberikan pakan berupa jerami secara langsung (Gambar 1). Sesuai yang dilaporkan oleh (Priady, 2016) bahwa jenis pakan yang diberikan adalah daun tebu, jerami jagung, rumput lapangan tanpa dipotong-potong dahulu ataupun melakukan pengawetan hijauan.

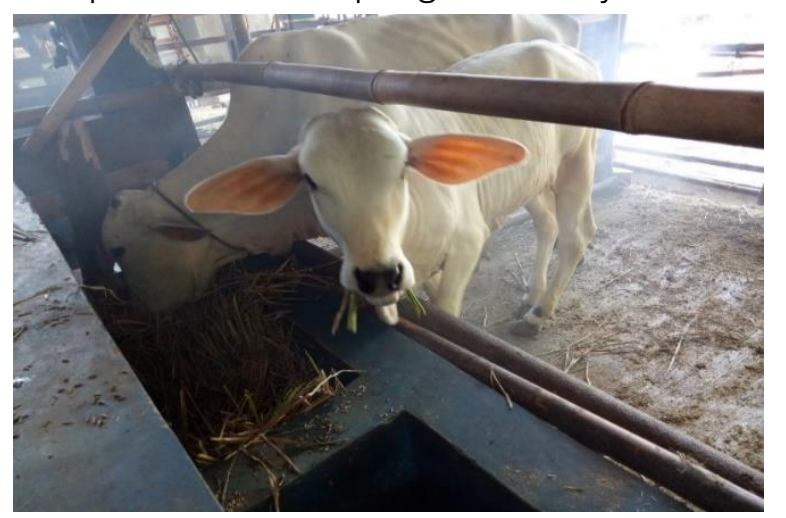

Gambar 1 Ternak Diberi Pakan Berupa Jerami Secara Langsung.

Sebagai sumber pakan, jerami mempunyai beberapa kelemahan yaitu kandungan lignin dan silika yang tinggi tetapi rendah energi, protein, mineral dan vitamin (Yanuartono, 2017). Jerami memiliki nutrisi dan kecernaan yang rendah karena sulit didegradasi oleh mikroba rumen (Van Soest, 2006; Sarnklong et al., 2010). Selain itu kelemahan lain dari jerami adalah jerami memiliki faktor pembatas seperti zat anti nutrisi (Mathius dan Sinurat, 2001) serta palatabilitasnya rendah (Tillman et al., 1998).

Penyediaan pakan ruminansia secara kontinyu, berkualitas dan praktis merupakan kebutuhan bagi peternak. Kendala bagi peternak dalam penyediaan pakan terutama hijauan pakan diantaranya yaitu keterbatasan jumlah sumber pakan, jarak antara sumber pakan dan peternakan sehingga menyulitkan transportasi, kualitas nutrisi rendah, musim kemarau dan pakan yang bersifat kamba (Utari et al., 2012). Salah satu satu alternatif bahan pakan yang dapat digunakan untuk mengatasi kendala tersebut yaitu penggunaan limbah agroindustri. Limbah agroindustri berpotensi besar sebagai pakan ternak. Potensi limbah agroindustri yang dapat dimanfaatkan sebagai pakan ternak di Kabupaten Subang sangat berlimpah dengan kapasitas tampung diperkirakan sekitar 524.000 Satuan Ternak, bersumber dari produk samping tanaman pangan (jerami padi), tebu atau tanaman pakan ternak lainnya (Puslitbangnak 2016).

Limbah agroindustri yang memiliki kandungan gizi yang tinggi berpotensi Jurnal Pengabdian Kepada Masyarakat MEDITEG Volume 4, Nomor 1, Desember 2019 Copyright @ 2019 Jurnal Pengabdian Kepada Masyarakat MEDITEG 
menjadi bahan campuran pakan untuk ternak. Limbah agroindustri bisa berasal dari pabrik olahan pangan seperti limbah kecap, molase dari pabrik gula, ampas tahu, dll. Secara umum limbah agroindustri memiliki kandungan protein, kecernaan dan palatabilitas yang rendah disamping itu sifatnya yang voluminous menyulitkan dalam penanganan, baik pada saat transportasi maupun penyimpanannya, sehingga memerlukan suatu cara untuk meningkatkan nilai guna limbah agroindustri sebagai pakan (Utari, et al., 2012).

Selain memanfaatkan jerami sebagai bahan pakan ternak, peternak di KTT Budi Asih memberi campuran bekatul pada pakan yang diberikan. Bekatul memiliki kandungan protein kasar sebesar $12.0 \%$, serat kasar 5.2\%, lemak kasar 10.7\%, abu 7.7\% dan BETN 50.4\% (Hartadi, et al., 1980). Kandungan gizi yang lebih baik dibandingkan jerami. Akan tetapi harga bekatul yang terus meningkat menyebabkan peternak kesulitan. Harga bekatul per kg mencapai Rp. 3000 sangat berdampak terhadap biaya pemeliharaan.

Pemanfaatan limbah agroindustri yang kaya gizi memiliki potensi yang tinggi untuk dikembangkan dan diterapkan pada peternakan sapi di Kabupaten Subang. Salah satu limbah agroindustri yang dapat dimanfaatkan sebagai bahan penyusun pakan diantaranya adalah limbah kecap. Limbah kecap berupa ampas merupakan bahan yang memiliki kandungan protein yang cukup tinggi, dimana $65 \%$ kandungan protein pada kedelai masih tertinggal di dalam ampas kecap. Ampas kecap dapat digolongkan sebagai sumber protein tinggi karena mengandung protein kasar lebih dari 18\% (Mayangsari et al., 2013). Selain itu ampas kecap mudah untuk didapatkan dan harganya leboh murah dibandingkan dengan harga bekatul.

Complete feed adalah ransum lengkap yang diformulasikan sedemikian rupa sehingga mengandung semua nutrisi sesuai dengan kebutuhan ternak (Baba, et al., 2012). Complete feed merupakan suatu strategi pemberian pakan yang telah lama diterapkan, khususnya pada industri sapi perah (Ginting, 2009). Pemberian pakan komplit terbukti dapat memenuhi kebutuhan nutrisi terutama untuk sapi yang sedang laktasi. Pakan komplit lebih menjamin meratanya distribsi asupan harian ransum, agar fluktuasi kondisi ekosistem di dalam rumen diminimalisir (Tajaj, et al., 2007). Penggunaan limbah agroindustri yang cepat rusak dapat dimanfaatkan menjadi bahan campuran pakan komplit. Pencampuran limbah basah dengan bahan pakan lain yang relatif kering untuk menyusun pakan komplit dapat mengurangi biaya pengeringan (Xu et al., 2007).

Berdasarkan dari pemaparan dan analisis situasi di KTT Budi Asih. Terdapat dua permasalahan yang dihadapi oleh mitra yaitu (1) rendahnya produktivitas ternak dan (2) mahalnya harga pakan yang biasa digunakan sehingga berpengaruh pada biaya operasional peternakan. 
Tujuan dari pengabdian yang dilakukan di KTT Budi Asih Kec. Cipunagara ini adalah untuk memanfaatkan limbah agroindustri berupa ampas kecap sebagai bahan penyusun complete feed sebagai solusi permasalahan pakan mahal dan untuk memberikan penyuluhan serta pelatihan pembuatan complete feed kepada masyarakat.

Luaran yang hendak dicapai dalam pengabdian masyarakat ini adalah meningkatkan pengetahuan peternak untuk pengembangan pembuatan pakan complete feed dari hasil limbah agroindustri sehingga dapat meningkatkan produktivitas ternak. Pemanfaatan limbah ampas kecap dapat menjadi alternatif solusi menanggulangi harga bahan pakan yang mahal, meskipun begitu ampas kecap masih memiliki nilai gizi yang tinggi.

\section{Metode}

Kegiatan pengabdian kepada masyarakat ini dilaksanakan di KTT Budi Asih di Desa Padamulya Kecamatan Cipunagara, Subang, Jawa Barat. Waktu pelaksanaan pengabdian masyarakat dilakukan dari bulan Agustus hingga Oktober 2018. Metode yang digunakan dalam pelaksaan kegiatan ini dilakukan dengan 3 tahapan yaitu :

1. Tahap pertama adalah tahap FGD dengan peternak anggota KTT Budi Asih, dari acara FGD ini diharapkan diperoleh titik permasalahan yang dihadapi oleh para peternak anggota (Gambar 2)

2. Penyuluhan dan pelatihan pembuatan pakan.

Merujuk dari hasil FGD sebelumnya maka solusi yang ditawarkan adalah pelakukan penyuluhan alternatif bahan pakan lain yang dapat dimanfaatkan sebagai pakan ternak adalah limbah dari industri kecap yang berupa kedelai fermentasi yang memiliki nilai gizi cukup tinggi, bahkan lebih tinggi jika dibandingkan dengan bekatul. Selain itu limbah kecap juga memiliki harga yang lebih rendah jika dibandingkan dengan bekatul.

Pemanfaatan pakan limbah agroindustri ini diformulasikan menjadi satu menjadi sebuah pakan komplit yang praktis dan mudah disimpan serta memiliki harga yang terjangkau. Formulasi pakan tersebut tersedia pada Tabel 1.

Setelah dilakukan penyuluhan maka dilakukan pelatihan pembuatan pakan komplit dengan bahan limbah agroindustri. Hasil formulasi dan pembuatan pakan ini kemudian diserahkan kepada para peternak untuk dapat dimanfaatkan sebagai pakan komplit untuk dicobakan pada ternak sapi potong.

3. Tahap Monitoring dan evaluasi, tahap ini dilakukan dengan memantau pemanfaatan pakan komplit yang telah dibuat serta produktivitas ternak yang dihasilkan. Produktivitas ternak dihitung dengan mencatat dan menghitung pertambahan bobot badan harian (PBBH) sapi. 
Pengamatan dan pencacatan bobot badan sapi dilakukan selama 15 hari.

\section{Hasil dan Pembahasan}

Kegiatan pengabdian masyarakat di KTT Budi Asih ini memiliki indikator keberhasilan yang diketahui dari adanya pemahaman peternak bahwa banyak bahan pakan lain dari limbah agroindustri yang dapat dimanfaatkan menjadi pakan ternak selain jerami dan bekatul. Selain itu adanya peningkatan keterampilan peternak dalam membuatan pakan komplit.

Adapun hasil yang dicapai dalam setiap tahapan kegiatan pengabdian masyarakat ini yaitu:

\section{Tahap FGD.}

Berdasarkan hasil FGD (Gambar 2) diperoleh hasil bahwa permasalahan yang dihadapi adalah mahalnya biaya pakan konsentrat berupa bekatul. Peternak berharap adanya alternative pakan lain yang harganya lebih murah dan mudah didapatkan. Solusi yang ditawarkan oleh tim pengabdian adalah dengan memanfaatkan limbah agroindustri seperti ampas kecap yang memiliki nilai gizi tinggi dan harga lebih murah dibandingkan dengan bekatul.

Ampas kecap didapatkan dari pabrik kecap milik PT. Anugrah Mutu Bersama (Bango Factory) yang terdapat di Kabupaten Subang. Harga ampas kecap yang dibeli adalah Rp. 2000/kg lebih rendah dibandingkan harga bekatul yang biasa dibeli para peternak. Harga yang lebih murah berbanding terbalik dengan kandungan gizi berupa protein yang lebih tinggi dibanding dengan bekatul. Ampas kecap dapat digolongkan sebagai sumber protein tinggi karena mengandung protein kasar lebih dari 18\% (Mayangsari et al., 2013).

Sebagian besar sapi yang dimiliki oleh KTT Budi Asih adalah sapi bakalan dimana usianya pada rentang 1-2 tahun. Pakan sapi yang digemukan ditujukan untuk membentuk daging dan lemak badan (Umiyasih dan Anggraeny, 2007). Pakan dengan kandungan protein yang tinggi sesuai untuk pembesaran sapi potong. Pakan harus mengandung protein dan energi yang memenuhi kebutuhan untuk pertumbuhan, pemeliharaan tubuh dan pembentukan lemak (Umiyasih dan Anggraeny, 2007).

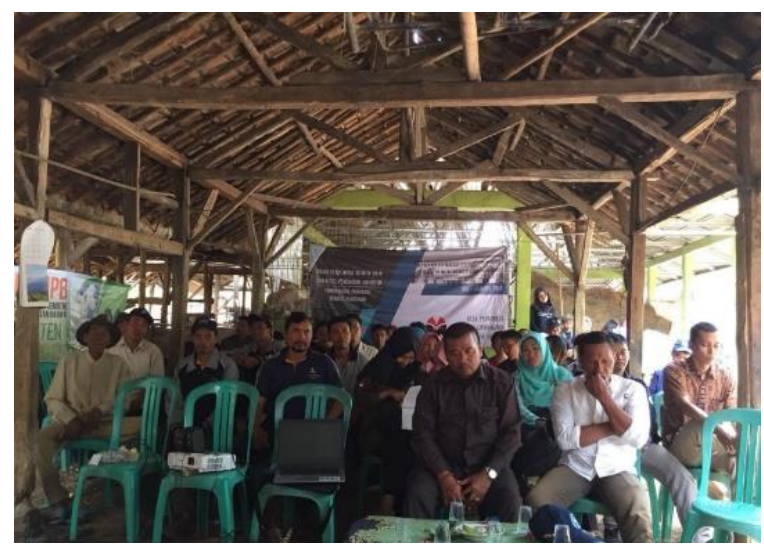

Gambar 2 Kegiatan Focus Group Discussion (FGD) dengan Masyarakat dan Peternak di Kecamatan Cipunagara.

\section{Tahap Penyuluhan.}

Pada tahap penyuluhan diperoleh hasil meningkatnya pengetahuan peternak 
anggota KTT Budi Asih dalam pentingnya memperhatikan kualitas dan kuantitas pakan yang diberikan pada sapi potong mereka. Pada tahap ini juga diperoleh hasil meningkatnya pengetahuan peternak tentang alternatif bahan pakan berutrisi yang dapat dimanfaatkan sebagai bahan pakan ternak yang berasal dari limbah agroindustri.

Pemaparan mengenai peranan masingmasing bahan penyusun complete feed dijelaskan sehingga peternak dapat mengetahui dan mengidentifikasi bahanbahan alternatif dengan peranan gizi yang sama. Formulasi pakan komplit yang digunakan pada pengabdian masyarakat terdiri dari jerami padi yang sudah digiling, tongkol jagung, limbah kedelai kecap berupa ampas, bekatul, molases dan garam yang bisa meningkatkan palatabilitas. Formulasi lengkap kapan komplit tersedia pada Tabel 1.

Tabel 1 Formulasi Pakan Komplit dari Limbah Kecap

\begin{tabular}{cll}
\hline No & Bahan & $\begin{array}{l}\text { Jumlah } \\
(\%)\end{array}$ \\
\hline 1 & Jerami Padi (giling) & 35 \\
\hline 2 & Tongkol Jagung (giling) & 35 \\
\hline 3 & Limbah kedelai kecap & 18 \\
\hline 4 & Bekatul & 10 \\
\hline 5 & Molases & 2 \\
\hline 6 & Garam & 0,2 \\
\hline
\end{tabular}

\section{Tahap Pelatihan Pembuatan Pakan Komplit}

Pada tahap ini diperoleh hasil meningkatnya keterampilan peternak dalam mengolah limbah agroindustri menjadi pakan komplit. Pakan komplit yang dibuat dengan formulasi yang telah dijelaskan pada saat penyuluhan. Pembuatan pakan komplit diawali dengan menyiapkan alat dan bahan sesuai formulasi. Melakukan penimbangan bahan sesuai dengan persentase yang telah ditentukan (Gambar 3).

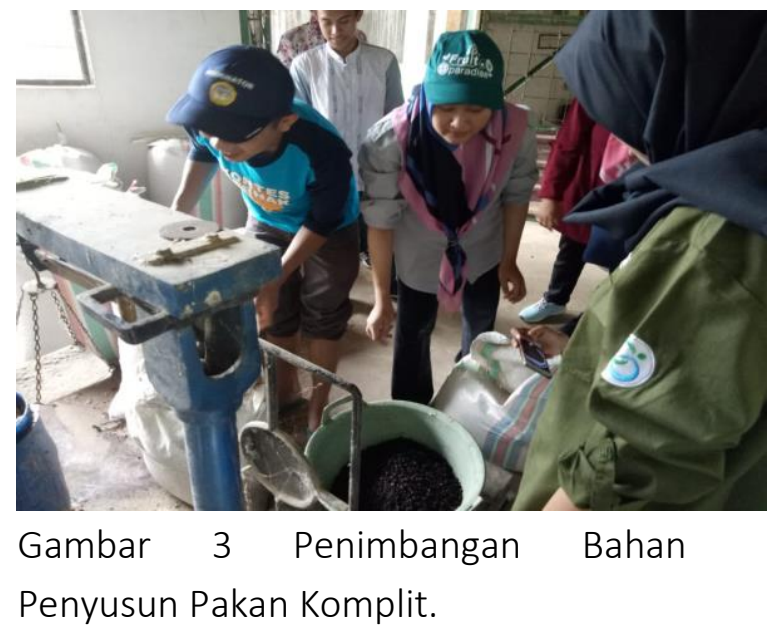

Pembuatan pakan yang dilakukan sebanyak 2 kali selama masa pengabdian. Pembuatan pakan pertama dengan memproduksi pakan sebanyak $500 \mathrm{~kg}$. Proses pembuatan pakan dibagi menjadi beberapa kelompok. Bahan pakan yang telah ditimbang kemudian dicampur secara merata.

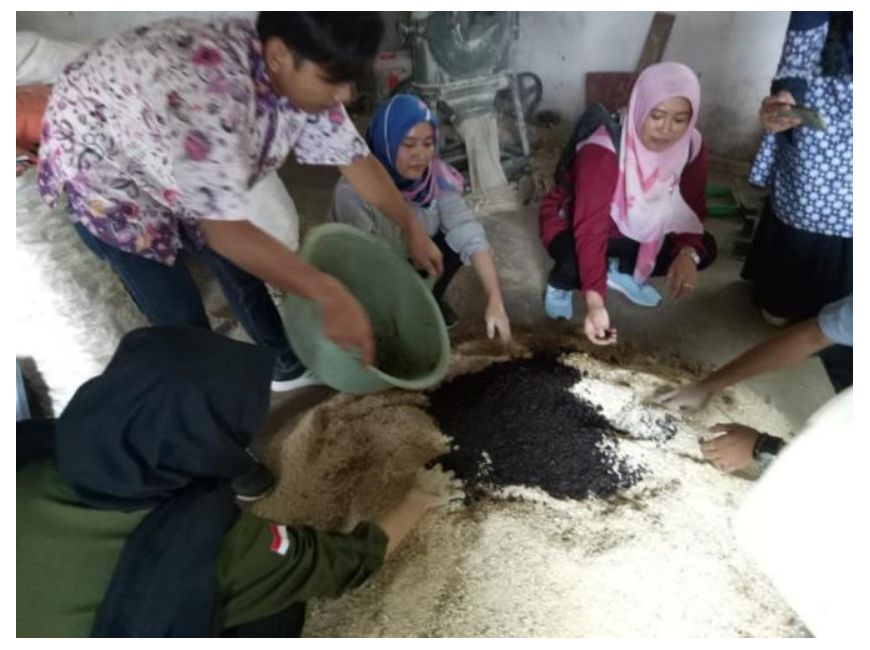

Jurnal Pengabdian Kepada Masyarakat MEDITEG

Volume 4, Nomor 1, Desember 2019

Copyright $\odot 2019$ Jurnal Pengabdian Kepada Masyarakat MEDITEG 
Gambar 4 Pembuatan Pakan Komplit dari Limbah Kecap

Proses pencampuran dilakukan secara bertahap, pencampuran pertama terdiri dari jerami dengan tongkol jagung yang keduanya telah digiling terlebih dahulu (adonan I). Setelah kedua bahan tercampur dengan merata kemudian tambahkan ampas kecap pada adonan I tersebut (Gambar 4). Campurkan bekatul, molases dan garam secara merata (adonan II). Terakhir, campurlah adonan I dan adonan II hingga tercampur dengan sempurna. Pakan komplit siap diberikan pada sapi (Gambar 5).

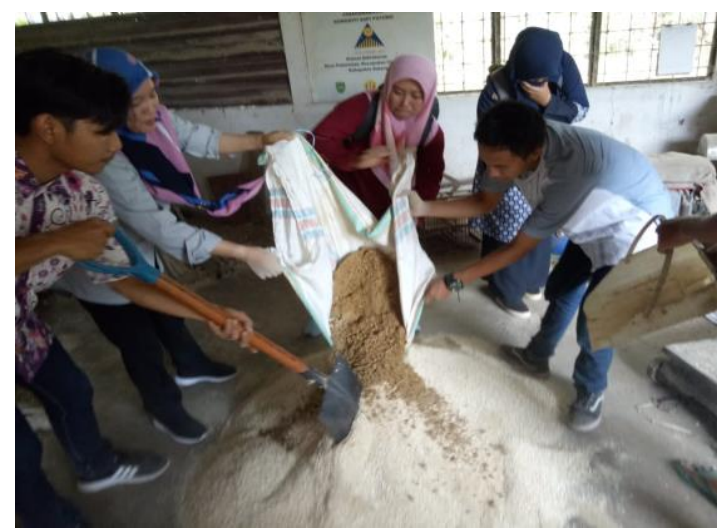

Gambar 5 Proses Pencampuran Adonan | dengan Adonan ||

Pakan komplit yang sudah tercampur rata kemudian dikemas pada plastikplastik dengan isi masing-masing kemasan $3.5 \mathrm{~kg}$. Pakan komplit diberikan sebanyak $3 \%$ dari bobot badan ternak (Gambar 6).

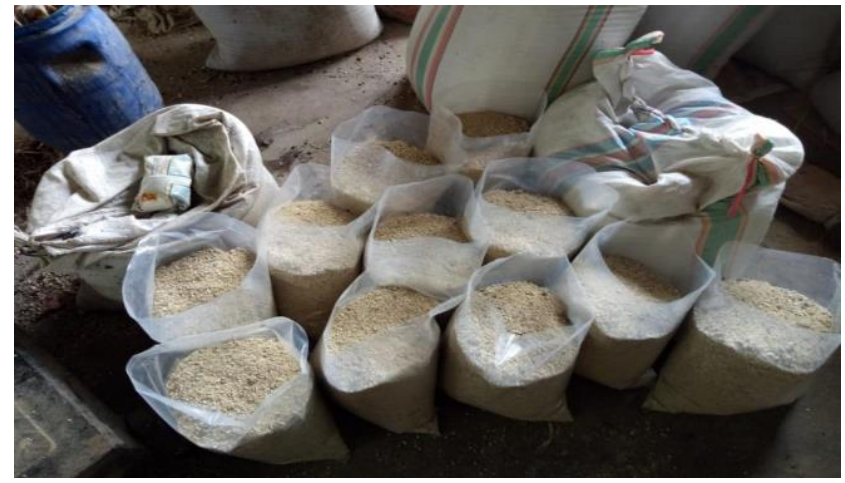

Gambar 6 Pakan yang telah ditimbang dalam kemasan

Setelah pelatihan pembuatan pakan selesai, kemudian dilakukan penyerahan pakan secara simbolis kepada pihak KTT Budi Asih oleh tim pengabdian (Gambar 7).

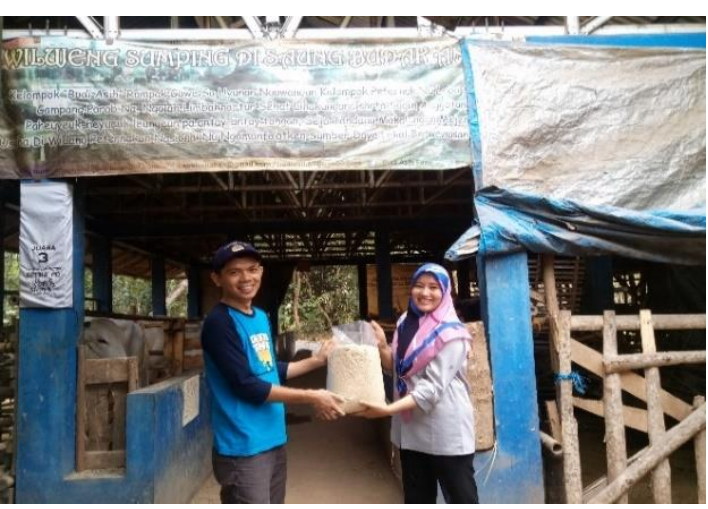

Gambar 7 Penyerahan Pakan Komplit secara simbolis.

\section{Tahap Monitoring dan Evaluasi.}

Tahap monitoring dan evaluasi yang dilakukan oleh tim pengabdian masyarakat dan UPPM Politeknik Negeri Subang (Gambar 8). Monitoring yang dilakukan adalah pemantauan pemberian pakan pada ternak selama 15 hari. Hasil Monitoring dan evaluasi yaitu diperolehnya PBBH pada ternak sapi potong milik KTT Budi Asih tersedia pada Tabel 2. 


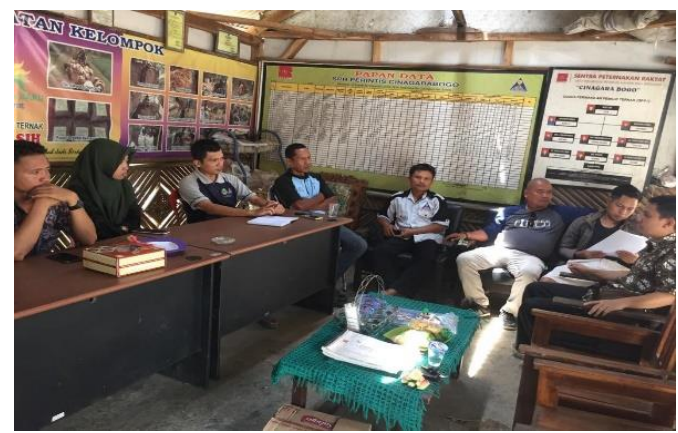

Gambar 8 Pelaksanaan Monitoring dan Evaluasi Kegiatan Pengabdian Masyarakat.

Tabel 2 Pertambahan Bobot Bahan Harian (PPBH) Sapi di KTT Budi Asih
Asih dalam memecahkan permasalahan yang dihadapi. Kegiatan pengabdian masyarakat yang dilakukan mampu meningkatkan pengetahuan dan keterampilan peternak dalam memanfaatkan limbah agroindustri yang potensial menjadi pakan komplit. Penggunaan limbah agroindustri sebagai pakan komplit dapat menekan biaya produksi serta meningkatkan produktivitas ternak dengan $\mathrm{PBBH}$ rata-rata 1.02 kg/ hari.

\section{Daftar Pustaka}

\begin{tabular}{|c|c|c|c|c|}
\hline Sapi (jenis) & $\begin{array}{l}\text { BB } \\
\text { awal }\end{array}$ & $\begin{array}{l}\text { Kg } \\
\text { pakan/ } \\
\text { hari }\end{array}$ & $\begin{array}{l}\text { BB } \\
\text { akhir }\end{array}$ & $\begin{array}{l}\text { (kg/hagihd A. Muktiani, "Produksi Complete } \\
\text { (kgand, Dagong M. I., A. Ako, A. Sanusi, }\end{array}$ \\
\hline $1(\mathrm{PO})$ & $288 \mathrm{~kg}$ & 8.6 & $300 \mathrm{~kg}$ & 0.85 Feed Berbahan Baku Lokal Dan Mu \\
\hline 2 (Limousin) & $237 \mathrm{~kg}$ & 8 & $251 \mathrm{~kg}$ & 1.00 Melalui \\
\hline $3(\mathrm{PO})$ & $186 \mathrm{~kg}$ & 7 & $202 \mathrm{~kg}$ & 1.14 Technology \\
\hline 4 (Limousin) & $116 \mathrm{~kg}$ & 6 & $133 \mathrm{~kg}$ & ningkatkan Produksi Dangke Susu \\
\hline $5(\mathrm{PO})$ & $266 \mathrm{~kg}$ & 3.5 & $279 \mathrm{~kg}$ & Kabupaten Enrekang," Pr \\
\hline
\end{tabular}

Berdasarkan dari data PBBH yang didapat, diketahui bahwa pakan komplit yang diberikan memberikan peningkatan bobot badan yang cukup baik. Menurut Edy, Anna dan Sularno (2005), pertambahan bobot badan peranakan sapi liomusin 0,88 kg/hari sedangkan sapi PO $0,78 \mathrm{~kg} /$ hari.

Penambahan bobot badan sapi yang baik akan menyebabkan waktu pemeliharaan lebih singkat. Pemberian pakan komplit menjadi solusi terbaik untuk meningkatkan produktivitas ternak.

\section{SIMPULAN}

Pelaksanaan kegiatan pengabdian masyarakat mampu membantu KTT Budi
Penampilan Produksi Sapi Peranakan Ongole dan Sapi Peranakan Ongole $X$ Limousin Yang Mendapat Pakan Rumput gajah dan Ampas Bir. http://eprints.undip.ac.id/21243/1/11 Ginting, S.P. 2009. Prospek Penggunaan Komplit Pada Kambing : Tinjauan Manfaat dan Aspek Bentuk Fisik Pakan Serta Respon Ternak. Wartazoa Vol. 19 No 2

Hartadi H, Reksohadiprojo S, Lebdosukojo S, Tillman AD. 1980. Tabel-tabel komposisi bahan makanan ternak untuk Indonesia. Logan (USA): International Feedstuffs Institute Utah 
Agricultural Experiment Station, Utah State University.

K. Pertanian, Pengembangan kawasan peternakan jawa barat tahun 2016, no. 358. Jakarta: Kementerian Pertanian Republik Indonesia, 2016.

Mathius, I. W., dan Sinurat. A. P. 2001. Pemanfaatan bahan pakan inkonvensional untuk ternak. Wartazoa 11 (2): 20-31.

Mayangsari N.S, Subrata A dan Christiyanto M. 2013 Pengaruh Proteksi Protein Ampas Kecap dengan Tanin Terhadap Konsentrasi Amonia, Produksi Protein Total dan Persentase Rumen Undegraded dietary Protein secara In Vitro. Animal Agriculture Journal Vol. 2, p 261-268

Priady S. D., Wiyatna M.F., Firman A. 2016. Penerapan Good Breeding Practice Terhadap Produktivitas Ternak Pada Peternakan Sapi Potong Rakyat. Fakultas Peternakan Universitas Padjadjaran. : Sumedang

Sarnklong, C., Cone, J. W., Pellikaan, W., and Hendriks. W. H. 2010. Utilization of Rice Straw and Different Treatments to Improve Its Feed Value for Ruminants: A Review. Asian-Aust. J. Anim. Sci. 23 (5) : 680 - 692. DOI: https://doi.org/10.5713/ajas.2010.80 619

Tillman, A. D., H. Hartadi, S. Reksohadiprodjo. 1998. Ilmu Makanan Ternak Dasar. Gadjah Mada University Press.Yogyakarta.
Umiyasih, U dan Anggraeny, Y.N. 2007. Petunjuk Teknis Ransum Seimbang, Strategi Pakan Pada Sapi Potong. Pusat Penelitian dan Pengembangan Peternakan: Pasuruan. ISBN : 978979-8308-70-3

Utari F.D, Prasetiyono B.W.H.E, dan Muktiani A. 2012. Kualitas Susu Kambing Peranakan Ettawa yang diberi Suplementasi Protein Terproteksi dalam Wafer Pakam Komplit Berbasis Limbah Agroindustri. Animal Agriculture Journal Vol. 1. No. 1 p 427-441

Van Soest, P. 2006. Rice Straw, the Role of Silica and Treatments to Improve Quality. Animal Feed Science and Technology, 130 (1-4):137-171. http://doi.org/10.1016/j.anifeedsci.20 06.01 .023

$\mathrm{Xu}$, Chuncheng, Y. Cai, N. Moriya and M. OGAWA. 2007. Nutritive value for ruminants of green tea grounds as a replacement of brewers' grains in totally mixed ration silage. Anim. Feed Sci. Technol. 138: $228-238$.

Yanuartono, Purnamaningsih $\mathrm{H}$, Indarjulianto S, Nururrozi A. 2017. Potensi Jerami Sebagai Palan Ternak Ruminansia. Jurnal IImu-IImu Peternakan 27(1):40-62 http://jiip.ub.ac.id/ 


\section{Riwayat Hidup PENULIS}

\section{Nurul Mukminah, S.Pt., M.Si.}

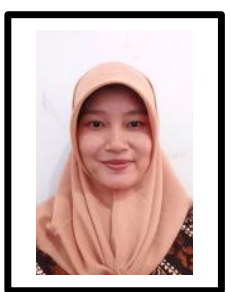

Lahir di Demak, 24 Maret 1989. Staf pengajar di Program Studi Agroindustri, Politeknik Negeri Subang. Studi S1 Jurusan Produksi Ternak, Fakultas Peternakan Universitas Diponegoro, Semarang, lulus tahun (2012); S2 bidang Ilmu Ternak, Universitas Diponegoro, Semarang, lulus tahun (2015); Infromasi publikasi . 1) Excretions of Urinary Creatinine on Young and Mature Kacang Goat under Different Feeding Levels. 2) Effects of Different Feeding Methods on Feeding Behavior, Feed Intake and Digestibility of Lactating Dairy Cows. 3) Profitabilitas Usaha Peternakan Ayam Broiler Dengan Tipe Kandang Yang Berbeda.

Irna Dwi Destiana, S.Pd., M.Si.

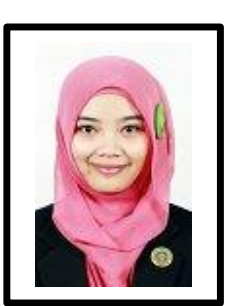

Lahir di Cianjur, 30 Desember 1991. Staf pengajar di Program Studi Agroindustri, Politeknik Negeri Subang. Studi S1 Pendidikan Teknologi Agroindustri Universitas Pendidikan indonesia, Bandung, lulus tahun (2012); S2 bidang Teknologi Pascapanen, Institut Pertanian Bogor, Bogor, lulus tahun (2015); Infromasi publikasi: 1)Pengemasan Benih Kedelai dengan Menggunakan Plastik untuk Meningkatkan Daya Simpan. 2) Pengaruh Beberapa Kemasan Plastik Terhadap Kualitas Benih Kedelai Selama Penyimpanan. 3) Biosensor dari Ekstrak Antosianin Bunga Telang Untuk Mendeteksi kebusukan pada Fillet Ikan Tenggiri

\section{Wiwik Endah Rahayu, S.TP, M.Si.}

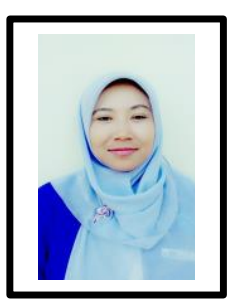

Lahir di Karang Endah, 28 November 1983. Staf pengajar di Program Studi Agroindustri, Politeknik Negeri Subang. Studi S1 teknik Pertanian, Universitas Sriwijaya, Palembang, lulus tahun (2005); S2 Bidang Ilmu Pertanian, Universitas Riau, Pekan Baru, lulus tahun (2012); Infromasi publikasi: 1) Daya Terima Varian Rasa Koktail
Buah Nanas (Ananas comosus L. Merr) Dalam Menunjang Diversifikasi Produk. 2) penggunaan media tanam dan pupuk npk terhadap hasil umbi rumput teki (cyperus rotundus) serta analisa kandungan keripik Olahannya.

\section{Enceng Sobari, S.P, M.Si.}

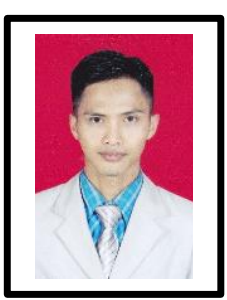

Lahir di Bandung, 05 Januari 1987. Staf pengajar di Program Studi Agroindustri, Politeknik Negeri Subang. Studi S1 Jurusan Agroteknologi, Universitas Islam Negeri Sunan Gunung Jati, Bandung, lulus tahun 2011; S2 bidang Agronomi, Universitas Padjadjaran, Bandung, lulus tahun (2015); Infromasi publikasi . 1) Efektifitas Penyiangan Terhadap Hasil Tanaman Wortel (Daucus carota L.) Lokal Cipanas Bogor. 2 Keragaman Genetik dan Kekerabatan Genotip Kacang Bambara (Vigna subteranea L.) Lokal Jawa Barat 3) Buku : Teknologi Pengolahan Pangan. 